\title{
VARIATION IN LEAF PHENOL CONTENT DURING FLOWERING IN LITCHI (Litchi chinensis SONN.)
}

\author{
Narayan Lal", ES Marboh, AK Gupta, Abhay Kumar, AK Dubedi Anal, Vishal Nath \\ ICAR-National Research Centre on Litchi, Muzaffarpur, Bihar \\ Received - September, 2019; Revision - November 11, 2019; Accepted - November 27, 2019 \\ Available Online - December 25, 2019
}

DOI: http://dx.doi.org/10.18006/2019.7(6).569.573

KEYWORDS
Litchi
Genotypes
Flowering
Phenol
Flavonoids

\begin{abstract}
To assess the role of phenol in flowering of litchi, an experiment was conducted at ICAR-NRC on Litchi, Muzaffarpur. Twenty desired litchi genotypes were selected and content of leaf phenol and leaf flavonoids were estimated from flowering and non-flowering trees. Results revealed that phenol content varied from $22.86-53.59 \mathrm{mg} / \mathrm{g}$ in flowering tree while it ranged from $10.03-33.7 \mathrm{mg} / \mathrm{g}$ in non-flowering tree during 2017. Among flowering genotypes phenol content was ranged from $16.51-50.35 \mathrm{mg} / \mathrm{g}$. The highest phenol content was recorded in genotypes IC-0615590 $(53.59 \mathrm{mg} / \mathrm{g})$ whereas lowest was found in genotype IC$0615589(22.86 \mathrm{mg} / \mathrm{g})$ during 2017 . The difference in phenol content between flowering and non-flowering tree ranged $12.74-66.09 \%$. The genotype Coll. 39 contained $66.09 \%$ more phenol in flowering tree as compared to non-flowering trees in 2017 and IC-0615597 possessed $12.74 \%$ more phenol in flowering tree as compared to non-flowering tree during the same period. Similarly, phenol content ranged from $6.45-$ $31.17 \mathrm{mg} / \mathrm{g}$ in non-flowering tree in 2018. In 2018, phenol content followed the same trend registering the maximum content in genotype IC-0615590 (50.35 mg/g) and lowest in IC-0615593 (16.51 mg/g). The difference in phenol content between flowering and non-flowering tree in 2018 ranged from 3.27 - 71.46 $\%$. The genotype IC-0615604 possessed $71.46 \%$ more phenol in flowering tree as compared to nonflowering tree and IC-0615593 contained $3.27 \%$ more phenol in flowering tree as compared to nonflowering tree. In general, it was observed that the level of phenol in litchi tree varied from year to year but flowering tree always possessed more content of phenol as compared to non-flowering trees. However, the relation of flavonoids and flowering in litchi was not observed.
\end{abstract}

* Corresponding author

E-mail: narayanlal.la17@gmail.com (Narayan Lal)

Peer review under responsibility of Journal of Experimental Biology and Agricultural Sciences.

Production and Hosting by Horizon Publisher India [HPI] (http://www.horizonpublisherindia.in/).

All rights reserved.
All the articles published by Journal of Experimental Biology and Agricultural Sciences are licensed under a Creative Commons Attribution-NonCommercial 4.0 International License Based on a work at www.jebas.org.

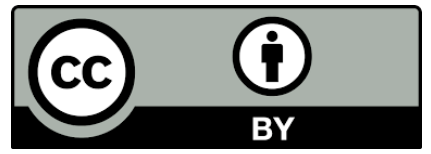




\section{Introduction}

Litchi (Litchi chinensis Sonn.) is an evergreen subtropical fruit of India. It is the most important fruit plant among other species including Longan (Dimocarpus longan Lour.), Rambutan (Nephelium lappaceum L.), Ackee (Blighia sapida Koen.), Pulasan (Nephelium mutabile Blume.), Momoncillo (Melicocca bijuga), Kusum (Pistacia oleosa Lour) and Guarana (Paullinia cupana H.B.K.) of the family Sapindaceae and sub-family Nepheleae, which has about 150 genera and more than 2000 species (Lal et al., 2017a). Originating from southern China, litchi needs cool and dry environmental condition especially during flower bud differentiation for flower induction, flowering and fruiting (Davenport \& Stern, 2005). Environmental factors especially temperature significantly affects fruit retention (Lal et al., 2017b). Being highly specific in climatic requirements, the expansion of litchi cultivation to newer areas with insufficient chilling temperature greatly increased problems of irregular flowering and fruiting (Davenport \& Stern, 2005). The litchi tree completes its reproductive cycle in 3-4 months. Anthesis starts and fruit set takes place during March in Bihar condition and the success of fruit set depends on the sources of pollen grains (Lal et al., 2019a and b). Fruit is a heart, round or oblong-shaped nut when ripe, fleshy and indehiscent. A wide variation in litchi fruit quality parameters viz., TSS (17.04-19.98 $\left.{ }^{\circ} \mathrm{B}\right)$, ascorbic acid (14.62-47.50 $\mathrm{mg} / 100 \mathrm{~g})$, acidity (0.23-0.55 \%), total sugar (10.05-13.54\%), reducing sugar (7.69-10.78\%), TSS/acidity ratio (33.98-84.19), phenol in pericarp (7.5-62.2 mg GAE/g) and seed (23.01-59.93 mg $\mathrm{GAE} / \mathrm{g})$, and flavonoids in pericarp (0.73-59.93 mg CE/g) and seed (2.41-27.50 mg CE/g) have been reported (Lal et al., 2018a and b).

Litchi produces 4-5 flushes per year depending on climate and soil condition or cultural practices. The early and mid-season flushes significantly influence flowering in litchi. Some researchers opined that presence of an endogenous, hypothetical flowering stimulus called florigen (Goldschmidt, 1996; Davenport \& Nunez-Elisea, 1997) and plant hormones (Bernier et al., 1993) are indispensable for development and emergence of flower bud. Generally, irregular flowering is a major concern in litchi especially during juvenile phase of the tree but in some shy bearing cultivars (China and CHESS-II) maintained at National Active Germplasm site (NAGS), ICAR-NRCL, Muzaffarpur, alternate bearing is observed even in mature trees which ultimately reduce productivity of the crop. Though, irregular bearing is governed by many factors, the role of phenols in flowering of litchi has not been properly emphasized. Preliminary studies have indicated that phenol and flavonoids, as secondary metabolites varies greatly among genotypes which might have important role in flowering and fruiting. Phenolic compounds are secondary metabolites, which are produced in the shikimic acid of plants and pentose phosphate through phenyl propanoid metabolization (Randhir et al., 2004).
Phenolics are the most important secondary metabolites in litchi and it plays various roles in entire metabolic process for instance incorporating attractive substances to accelerate pollination, coloring for camouflage and defense against herbivores, as well as antibacterial and antifungal activities (Ahmad \& Tahir, 2017). These phenolic substances contain numerous varieties of compounds: simple flavonoids, phenolic acids, complex flavonoids and colored anthocyanins (Babbar et al., 2014). Flavonoids are involved in various metabolical processes like morphogenesis, photosensitization, energy transfer, respiration, photosynthesis, and impart plants an appealing taste and flavour which either attract or repels pollinator and pests (Harborne \& Williams, 2000). The present investigation was carried out with objective to assess the relationship between phenolics compounds (Phenol and Flavonoids) and litchi flowering.

\section{Materials and Methods}

Present study was conducted on twenty diverse litchi genotypes of 10 years old plants at ICAR - National Research Centre on Litchi, Muzaffarpur for two consecutive years (2017 and 2018). The study was conducted in randomized block design with three replications at spacing of 8 meters. All the standard agronomical practices were followed round the year. To establish the relation between phenolics and flowering, leaf samples were taken for estimation of phenol and flavonoids. Phenol and flavonoids from mature leaf was estimated as described by Vyas et al. (2015) with minor modification. For estimation of phenol, $200 \mathrm{mg}$ of leaf sample was taken in the second week of March during flowering in both the years and ground with $5 \mathrm{ml}$ of $80 \%$ ethanol and kept overnight. Next day, $0.1 \mathrm{ml}$ of aliquot was pipetted out in a test tube followed by $3 \mathrm{ml}$ of distilled water and $0.5 \mathrm{ml}$ of Folin-Ciocalteu reagent $(1 \mathrm{~N})$. After 3 minutes, $2 \mathrm{ml}$ of $20 \% \mathrm{Na}_{2} \mathrm{CO}_{3}$ solution was added and mixed thoroughly and the absorbance was read at $750 \mathrm{~nm}$ against blank. The calculation was done with the help of Gallic acid standard curve. Data recorded were subjected to statistical analysis utilizing an analysis of variance (ANOVA) test at a significance level of $\alpha=0.05$. All the analyses were performed with SAS software (version 2.0, SAS Software). Mean values subscripted with same alphabets are non-significant.

\section{Results and Discussion}

A great variation in phenol and flavonoid contents among the genotypes in flowering and non-flowering trees was observed. Phenol and flavonoids content in leaf of flowering and nonflowering trees for 2 consecutive years are presented in table 1 . During 2017, the phenol content in flowering genotypes varied from $22.86-53.59 \mathrm{mg} / \mathrm{g}$ while it ranged from $10.03-33.7 \mathrm{mg} / \mathrm{g}$ in non-flowering trees. In flowered genotypes, the highest phenol content recorded in genotype IC-0615590 (53.59 mg/g) while it was $30.95 \mathrm{mg} / \mathrm{g}$ in non-flowered trees whereas, the lowest phenol 
Table 1 Phenol and flavonoids in flowering and non-flowering tree of litchi genotypes

\begin{tabular}{|c|c|c|c|c|c|c|c|c|}
\hline \multirow{3}{*}{ Genotypes } & \multicolumn{4}{|c|}{ Phenol ( GAE mg/g) } & \multicolumn{4}{|c|}{ Flavonoids (CE mg/g) } \\
\hline & \multicolumn{2}{|c|}{2017} & \multicolumn{2}{|c|}{2018} & \multicolumn{2}{|c|}{2017} & \multicolumn{2}{|c|}{2018} \\
\hline & Flowering & $\begin{array}{c}\text { Non- } \\
\text { Flowering }\end{array}$ & Flowering & $\begin{array}{c}\text { Non- } \\
\text { Flowering }\end{array}$ & Flowering & $\begin{array}{c}\text { Non- } \\
\text { Flowering }\end{array}$ & Flowering & $\begin{array}{c}\text { Non- } \\
\text { Flowering }\end{array}$ \\
\hline IC-0615585 & $28.76^{\mathrm{i}}$ & $19.38^{f}$ & $33.45^{\mathrm{f}}$ & $23.33^{\mathrm{d}}$ & $10.30^{\mathrm{kl}}$ & $6.54^{1}$ & $19.47^{\mathrm{ef}}$ & $15.65^{\mathrm{h}}$ \\
\hline IC-0615587 & $31.37^{\mathrm{h}}$ & $23.48^{\mathrm{d}}$ & $29.56^{\mathrm{g}}$ & $20.97^{\mathrm{e}}$ & $13.70^{\mathrm{j}}$ & $13.04^{\text {hi }}$ & $14.33^{\mathrm{h}}$ & $20.5^{\mathrm{cd}}$ \\
\hline IC-0615589 & $22.86^{\mathrm{k}}$ & $11.11^{\mathrm{i}}$ & $19.88^{j}$ & $6.45^{\mathrm{g}}$ & $9.44^{1}$ & $12.88^{\mathrm{ij}}$ & $8.75^{\mathrm{k}}$ & $13.13^{\mathrm{i}}$ \\
\hline IC-0615590 & $53.59^{\mathrm{a}}$ & $30.95^{\mathrm{b}}$ & $50.35^{\mathrm{a}}$ & $28.25^{\mathrm{b}}$ & $28.16^{\mathrm{a}}$ & $19.31^{\mathrm{e}}$ & $25.31^{\mathrm{a}}$ & $20.72^{c}$ \\
\hline IC-0615591 & $49.09^{\mathrm{bc}}$ & $24.07^{\mathrm{d}}$ & $37.22^{\mathrm{d}}$ & $20.41^{\mathrm{e}}$ & $17.04^{\text {fgh }}$ & $18.13^{\mathrm{f}}$ & $14.02^{\text {hi }}$ & $20.88^{\mathrm{c}}$ \\
\hline IC-0615592 & $41.99^{\mathrm{e}}$ & $23.07^{\mathrm{de}}$ & $40.18^{\mathrm{c}}$ & $21.62^{\mathrm{e}}$ & $27.36^{\mathrm{ab}}$ & $20.75^{\mathrm{d}}$ & $24.2^{\mathrm{ab}}$ & $19.18^{\mathrm{ef}}$ \\
\hline IC-0615593 & $23.36^{\mathrm{k}}$ & $14.78^{\mathrm{gh}}$ & $16.51^{\mathrm{k}}$ & $15.97^{\mathrm{g}}$ & $15.67^{\mathrm{hi}}$ & $11.89^{j}$ & $13.45^{\mathrm{hi}}$ & $11.83^{\mathrm{j}}$ \\
\hline IC-0615594 & $31.35^{\mathrm{h}}$ & $13.41^{\mathrm{h}}$ & $33.9^{\text {ef }}$ & $16.04^{\mathrm{g}}$ & $18.84^{\mathrm{dc}}$ & $15.52^{\mathrm{g}}$ & $22.04^{\text {cd }}$ & $17.01^{\mathrm{g}}$ \\
\hline IC-0615595 & $51.12^{\mathrm{b}}$ & $30.99^{b}$ & $47.42^{b}$ & $31.17^{\mathrm{a}}$ & $22.34^{\mathrm{c}}$ & $3.53^{\mathrm{m}}$ & $20.72^{\text {de }}$ & $3.92^{1}$ \\
\hline IC-0615596 & $48.61^{\mathrm{c}}$ & $33.7^{\mathrm{a}}$ & $39.79^{\mathrm{c}}$ & $30.39^{a}$ & $17.24^{\mathrm{fg}}$ & $10.15^{\mathrm{k}}$ & $17.99^{\mathrm{g}}$ & $7.04^{\mathrm{k}}$ \\
\hline IC-0615597 & $26.44^{\mathrm{j}}$ & $23.07^{\mathrm{de}}$ & $28.91^{\mathrm{g}}$ & $24.79^{c}$ & $3.25^{\mathrm{m}}$ & $2.75^{\mathrm{m}}$ & $3.59^{1}$ & $3.91^{1}$ \\
\hline Coll. 39 & $44.06^{\mathrm{d}}$ & $14.94^{\text {gh }}$ & $50.11^{\mathrm{a}}$ & $18.88^{\mathrm{f}}$ & $17.82^{\text {ef }}$ & $15.49^{\mathrm{g}}$ & $22.41^{\mathrm{c}}$ & $19.32^{\text {def }}$ \\
\hline IC-0615599 & $51.12^{\mathrm{b}}$ & $22.96^{\text {de }}$ & $49.42^{\mathrm{a}}$ & $17.33^{\mathrm{g}}$ & $21.06^{\mathrm{c}}$ & $7.25^{1}$ & $19.45^{\mathrm{ef}}$ & $2.15^{\mathrm{m}}$ \\
\hline IC-0615600 & $25.57^{\mathrm{j}}$ & $10.03^{\mathrm{i}}$ & $20.32^{\mathrm{j}}$ & $9.16^{\mathrm{hi}}$ & $16.22^{\mathrm{gh}}$ & $19.25^{\mathrm{ef}}$ & $12.67^{\mathrm{i}}$ & $20.13^{\text {cde }}$ \\
\hline IC-0615601 & $28.72^{\mathrm{i}}$ & $23.52^{\mathrm{d}}$ & $23.98^{\mathrm{i}}$ & $20.72^{\mathrm{e}}$ & $9.49^{1}$ & $18.65^{\mathrm{ef}}$ & $8.07^{\mathrm{k}}$ & $19.29^{\text {def }}$ \\
\hline IC-0615603 & $27.27^{\mathrm{ij}}$ & $13.7^{\mathrm{h}}$ & $24.12^{\mathrm{i}}$ & $8.12^{\mathrm{i}}$ & $17.88^{\mathrm{ef}}$ & $15.94^{\mathrm{g}}$ & $23.12^{\mathrm{bc}}$ & $18.61^{\mathrm{f}}$ \\
\hline IC-0615604 & $39.45^{\mathrm{f}}$ & $21.69^{\mathrm{e}}$ & $35.04^{\mathrm{e}}$ & $10^{\mathrm{h}}$ & $19.33^{\mathrm{d}}$ & $26.24^{\mathrm{b}}$ & $17.21^{\mathrm{g}}$ & $28.93^{\mathrm{a}}$ \\
\hline IC-0615605 & $39.83^{f}$ & $29.6^{\mathrm{c}}$ & $46.19^{b}$ & $28.07^{b}$ & $14.65^{\mathrm{i}}$ & $24.33^{\mathrm{c}}$ & $18.31^{\mathrm{fg}}$ & $27.53^{\mathrm{b}}$ \\
\hline IC-0615606 & $31.37^{\mathrm{h}}$ & $16.44^{g}$ & $27.51^{\mathrm{h}}$ & $17.14^{\mathrm{g}}$ & $10.99^{k}$ & $14.17^{\mathrm{h}}$ & $10.25^{\mathrm{j}}$ & $16.45^{\text {gh }}$ \\
\hline IC-0615611 & $34.13^{\mathrm{g}}$ & $29.6^{\mathrm{bc}}$ & $29.78^{g}$ & $26.84^{\mathrm{b}}$ & $26.28^{\mathrm{b}}$ & $30.39^{\mathrm{a}}$ & $23.99^{\mathrm{ab}}$ & $29.12^{\mathrm{a}}$ \\
\hline $\begin{array}{l}\text { LSD } \\
(\mathrm{P}=0.05)\end{array}$ & 2.03 & 1.68 & 1.36 & 1.43 & 1.44 & 1.14 & 1.42 & 1.22 \\
\hline
\end{tabular}

content was found in genotype IC-0615589 with $22.86 \mathrm{mg} / \mathrm{g}$ in flowering and $11.11 \mathrm{mg} / \mathrm{g}$ in non-flowering trees. The difference in phenol content between flowering and non-flowering tree ranged from $12.74 \%$ (IC-0615597) - $66.09 \%$ (Coll. 39) which was more in flowering trees as compared to non-flowering trees. Similarly, during 2018 , the range in phenol content was $16.51-50.35 \mathrm{mg} / \mathrm{g}$ (flowering trees) and $6.45-31.17 \mathrm{mg} / \mathrm{g}$ (non-flowering trees) and lowest was registered in genotype IC-0615593, recording a phenol content of $16.51 \mathrm{mg} / \mathrm{g}$ and $15.97 \mathrm{mg} / \mathrm{g}$ in flowering and nonflowering trees respectively. The difference in phenol content between flowering and non-flowering tree ranged from 3.27- 71.46 $\%$ which was maximum in genotype IC-0615604 and minimum in genotype IC-0615593 (Figure 1). Though, the level of phenol in litchi tree varied from seasonally but study revealed that flowering tree always possessed more content of phenol as compared to nonflowering trees at flowering stage. The phenol acts as analogues of hormone which trigger floral development in litchi.
The flavonoids content in leaf during 2017 ranged from 3.25-28.16 $\mathrm{mg} / \mathrm{g}$ in flowering tree and $2.75-30.39 \mathrm{mg} / \mathrm{g}$ in non-flowering trees while it varied from $3.59-25.31 \mathrm{mg} / \mathrm{g}$ and $2.15-29.12 \mathrm{mg} / \mathrm{g}$ in flowering and non-flowering trees respectively during 2018. As in phenol content, flavonoid content was also recorded highest in flowering trees compared to non-flowering trees and genotypes IC0615590, IC-0615592, and IC-0615611 showed maximum flavonoid content during both the years. In contrast, genotypes IC0615600, IC-0615604 and IC-0615606 possessed lower flavonoids in flowering tree as compare to non-flowering trees.

In this study, the level of phenol in leaf was found higher in flowered trees as compare to non-flowered trees. The phenol content in leaf has shown strong relation with flowering in litchi but the level of flavonoids did not follow any pattern and seems that it has no relation with flowering in litchi. The litchi flavonoids may have role in imparting colour to fruits. Kumar et al. (1978) 


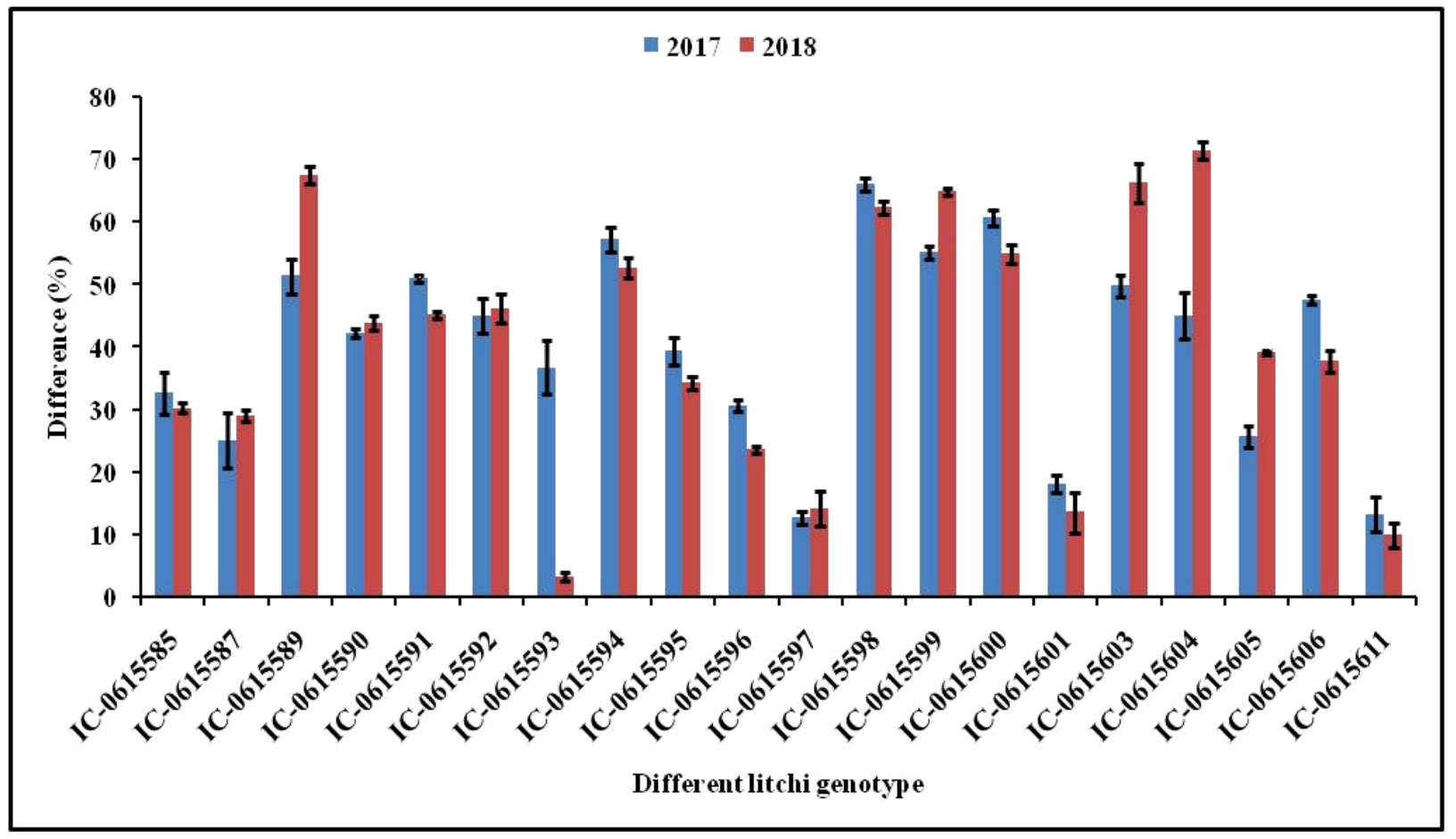

Figure 1 Per cent difference of leaf phenol content in flowering over non-flowering litchi genotypes in two successive years (2017 and 2018). Height of rows indicates the mean value of parameters. Error bar indicates standard error of the mean. The least significant difference (LSD) at $\mathrm{P}=0.05$ were 6.82 for 2017 and 4.79 for 2018 respectively.

also reported that phenolic compounds are able to induce maximum floral buds in I. balsamina. Datta et al. (1978) found a significant role of phenol in the mobilization of reserve food materials to the sinks for grain-filling process. The relation of higher content of phenol with flowering in litchi might be due to the mobilization of reserved food materials to shoots which promote floral bud differentiation resulting in good flowering.

In Neelum, a regular bearing mango cultivar, the highest level of total phenol content was recorded at flower and fruit bud differentiation (Kumar et al., 2014) which provide supporting evidence on the role of phenol in litchi flowering. Patel et al. (1992) found that phenolic content of fruit buds in mango was stable in undifferentiated (or) scar buds while it increased steadily with advancing flower bud differentiation. Besides ensuring good flowering and fruit set, phenols also played an important role in germination of pollen grain (Villar et al., 1987; Shivanna et al., 1989). Result presented here are first evidence that phenols could be involved in floral induction in litchi which could provide an alternative approach to regulate irregular flowering. There is paucity of reports elucidating the role of phenol in flowering in fruit trees. Hence, in order to validate the effect of phenol on flowering in litchi, the response of flower bud differentiation to external application of phenols needs to be quantifies.

\section{Conclusion}

The phenol content in leaf has great role in floral induction in litchi. Among genotypes, phenol content varies significantly in flowering and non-flowering trees. Comparatively, flowering genotypes have higher phenol content as compared to nonflowering trees, though the level of phenol in litchi tree varied from year to year. The phenol acts as analogues of hormone which trigger floral development in litchi. In contrast, flavonoids content in leaf was found higher in non-flowering trees comparatively. The flavonoids content in leaf varied irrespective of flowering and non-flowering trees. It can be concluded that flowering has direct relation with phenol but not with flavonoids.

\section{Acknowledgement}

The authors are thankful to Director, ICAR-NRC on Litchi, Muzaffarpur for providing necessary facilities to complete the work.

\section{Conflict of interest}

Authors would hereby like to declare that there is no conflict of interest that could possibly arise. 


\section{References}

Ahmad SS, Tahir I (2017) Regulatory role of phenols in flower development and senescence in the genus Iris. Indian Journal of Plant Physiology 22:135-140.

Babbar N, Oberoi HS, Sandhu SK, Bhargav VK (2014) Influence of different solvents in extraction of phenolic compounds from vegetable residues and their evaluation as natural sources of antioxidants. Journal of Food Science and Technology 51: 2568-2575.

Bernier G, Havelange A, Houssa C, Petitjean A, Lejeune P (1993) Physiological signals that induce flowering. The Plant Cell 5:1147-1155.

Datta KS, Kumar S, Nanda KK (1978) Effects of some phenolic compounds and gibberellic acid on flowering and yield characters of cheena millet (Panicum miliaceum L.). The Journal of Agriculture Science 91:731-735.

Davenport TL, Nunez-Elisea R (1997) Reproductive physiology In: Litz RE (Ed.), The Mango, Botany, Production and Uses, CAB International, Wallingford Oxon,UK, Pp.69-146.

Davenport TL, Stern RA (2005) Flowering. In: Menzel CM, Waite GK (Eds.) Litchi and Longan: Botany, Production and Uses. CAB International, Wellingford, Pp 87-113.

Goldschmidt EE (1996) Reproductive physiology. In: Spiegel-Roy, Litz, EE (Eds.), The mango. CAB International, Wallingford, UK, Pp.70-125.

Harborne JB, Williams CA (2000) Advances in flavonoid research since 1992. Phytochemistry 55: 481-504.

Kumar M, Ponnuswami V, Jeya Kumar P, Saraswathy S (2014) Influence of season affecting flowering and physiological parameters in mango. Scientific Research and Essays 9: 1-6.

Kumar S, Shabma R, Nanda KK (1978) Effect of gibberellic acid and some diphenols on the flowering of Impatiens balsamina L., a qualitative short day plant. Plant and Cell Physiology 19: 471-479.

Lal N, Gupta AK, Marboh ES, Kumar A, Nath V (2019b) Effect of pollen grain sources on success of hybrids in 'Bedana' Litchi. International Journal of Bio-resource and
Stress Management 10:241-45.

Lal N, Gupta AK, Marboh ES, Kumar A, Nath V (2019a) Effect of pollen grain sources on fruit set and retention in 'Shahi' litchi. Multilogic in Science 9:152-56.

Lal N, Gupta AK, Kushwah NS and Nath V (2017a) Sapindaceous Fruits In: Peter KV (Ed.) Horticultural Crops of High Nutritive values. Brillion Publishing, New Delhi, India, Pp 339-370.

Lal N, Gupta AK, Nath V (2017b). Fruit retention in different litchi germplasm influenced by temperature. International Journal of Current Microbiology and Applied Science 6: 1189-1194.

Lal N, Pandey SK, Nath V, Agrawal V, Gontia AS, Sharma HL (2018b) Total phenol and flavonoids in by-product of Indian litchi: Difference among genotypes. Journal of Pharmacognosy and Phytochemistry 7: 2891-2894.

Lal N, Pandey SK, Nath V, Gontia AS, Sharma HL (2018a) Evaluation of litchi (Litchi chinenesis Sonn.) genotypes for fruit quality attributes. International Journal of Chemical Studies 6: 2556-2560.

Patel PB, Rao MM, Srinivasan CN, Basarkar PW, Nalwadi VG (1992) Physiological and biochemical factors associated with fruit bud differentiation in Alphonso mango: V - total free phenols and polyphenol oxidase. Karnataka Journal of Agricultural Science 54:338-342.

Randhir R, Lin YT, Shetty K (2004) Stimulation of phenolics, antioxidant and antimicrobial activities in dark germinated mung bean sprouts in response to peptide and phytochemical elicitors. Process Biochemistry 39: 637-646.

Shivanna KR, Ciampolini F, Cresti M (1989) The structure and cytochemistry of the pistill of Hypericumcaycinum: the stigma. Annals of Botany 63:613-620.

Villar M, Gadet M, Said C. Knox RB, Dumas C (1987) Incompatibility in Populus: Structural and cytochemical chracteristics of the receptive stigma of Populous alba and $P$. nigra. Journal of Cell Science 87: 483-490.

Vyas S, Kachhwaha S, Kothari SL (2015) Comparative analysis of phenolic contents and total antioxidant capacity of Moringa oleifera Lam. Pharmacognosy Journal 7:44-51. 